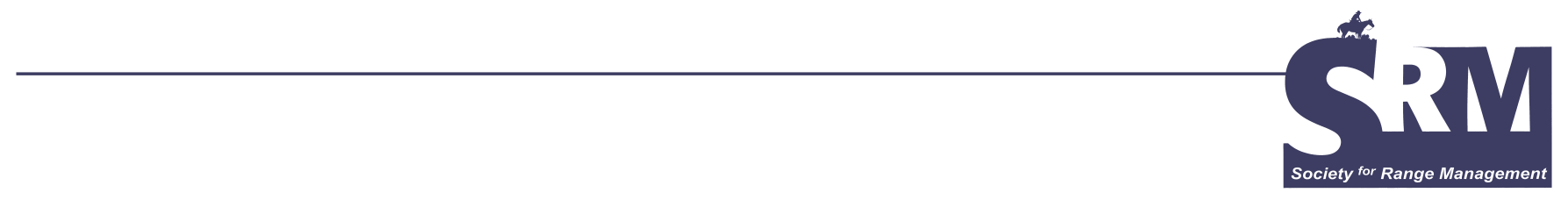

\title{
Vancouver, British Columbia: Host City for SRM 2006
}

\author{
Meet us in Vancouver for an SRM special-education \& culture rolled into one!
}

\section{By Michael Borman and Cindy Meays}

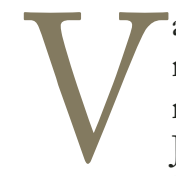

ancouver, described as "spectacular by nature," is nestled between the spectacular and scenic coastal mountain range and the Pacific Ocean (Fig. 1). Join us February 12-17 for the 2006 SRM annual meeting in beautiful Vancouver, BC. Bring your spouse or special guest, and family. Vancouver offers convenient access to skiing and fishing, exceptional and varied dining options, a vibrant cultural scene, and a multicultural environment that makes the city one of the most desirable places in the world to visit. Vancouver is the host city for the 2010 Winter Olympics.

\section{Hotels}

The Hyatt Regency Vancouver and the Fairmont Hotel Vancouver will be the headquarters hotels. The two hotels are across the street from each other and will house the entire meeting. They offer outstanding accommodations and are within easy walking distance of many of the city's attractions. The Royal Centre Mall, Pacific Centre, and Robson Street, Vancouver's exclusive shopping district, are in the immediate vicinity. Both hotels are within walking distance to parks, Gastown, Chinatown, and Vancouver's entertainment district. Stanley Park is just a few blocks away.

The Hyatt Regency (Fig. 2), with 34 stories and 644 guest rooms, features an outdoor heated swimming pool, health club, and access to racquetball and squash courts. A modern world-class convention hotel, it offers dining choices including the European-style Latte Café \& Bistro and the Mosaic Bar \& Grill, which features dishes from around the

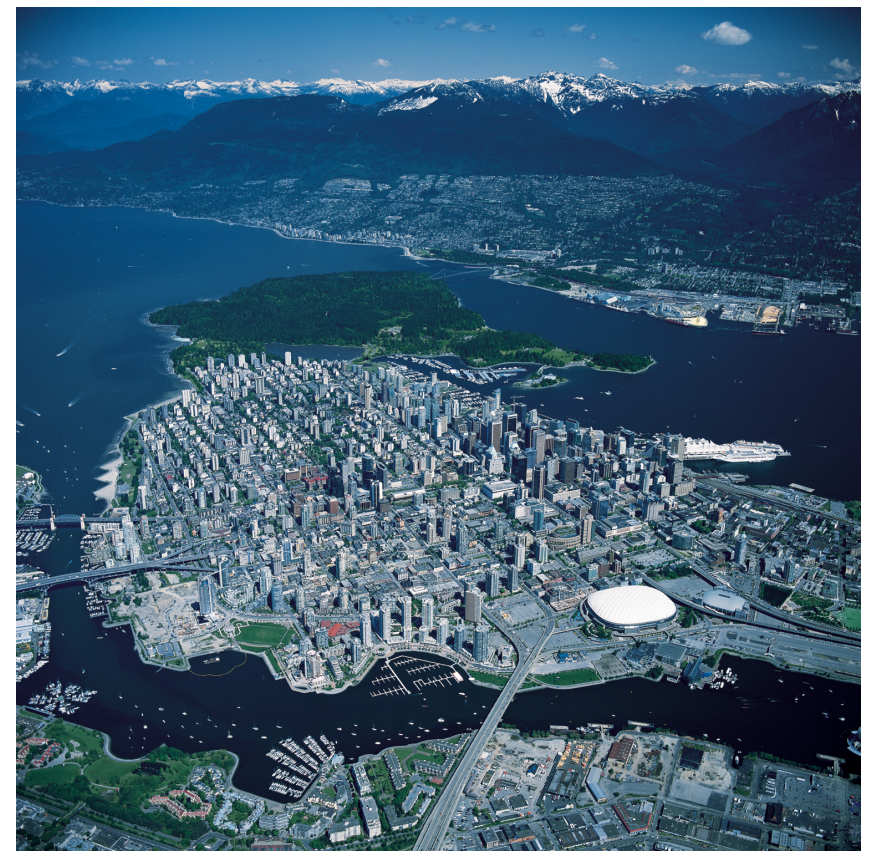

Figure 1. An aerial view of downtown Vancouver. Photo courtesy of Tourism Vancouver.

world prepared with a "West Coast flair." Each guest room includes TV, 2-line dataport phones, individual climate control, a hair dryer, bathrobes, umbrellas, a coffeemaker, and other amenities. 


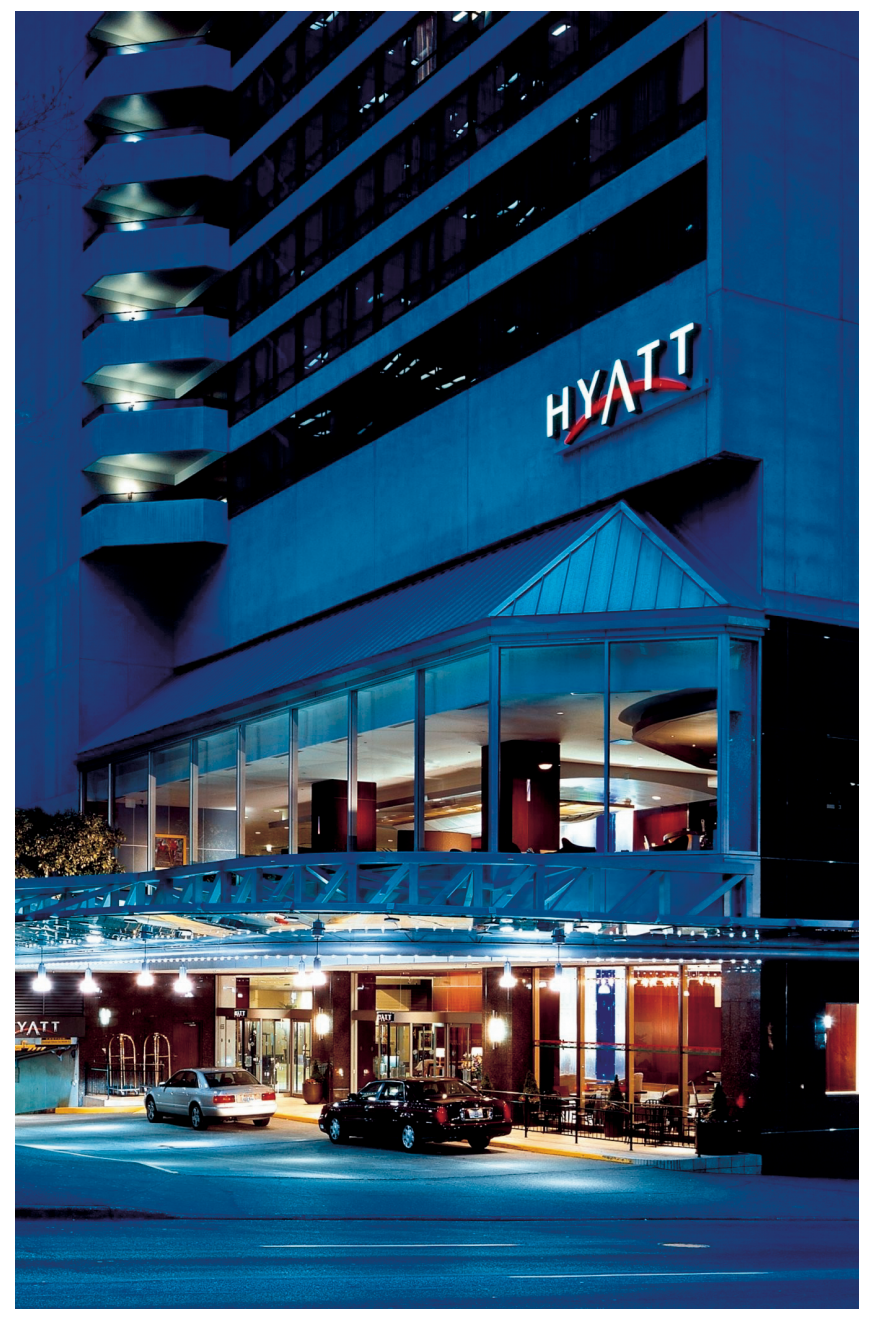

Figure 2. Front entrance to the Hyatt Regency Vancouver. Photograph courtesy of the Hyatt Regency hotel.

The Fairmont Hotel Vancouver, one of the majestic railway hotels that were built across the country by the Canadian Pacific and the Canadian National railways, was finished in 1939 in time for the arrival of King George VII and Queen Elizabeth I. It was completely restored in the 1990s and unites the timeless glamour of its era with the luxury and services desired by today's traveler. The hotel offers a state-of-the-art health club, an indoor pool, hot tub, sauna, spa, designer shops, and two award-winning restaurants. The 556 Fairmont guest rooms are spacious and beautifully furnished with reproduction antiques including a large working desk. Each room offers voice mail, Internet access, bathrobes, coffeemaker with complimentary tea and coffee, a $\mathrm{TV}$, and other amenities.

\section{Climate}

Warmed by Pacific Ocean currents and protected by a range of mountains, Vancouver enjoys mild temperatures year round. February's average lows are in the mid-30s and highs are in the mid-40s Fahrenheit $\left(0^{\circ}\right.$ to $5^{\circ}$ Celsius). Winters are wet, but it rarely snows, except on local ski hills.

\section{Skiing and Snowboarding}

If you enjoy skiing and snowboarding, Greater Vancouver has three local mountains-Cypress, Grouse, and Seymour-on Vancouver's North Shore. Whistler Blackcomb, site of the upcoming 2010 Winter Olympics' ski events, has been rated the top ski destination in North America and is approximately two hours north of Vancouver.

\section{Host Activities-Tours}

The Greater Vancouver area does not have rangelands to offer in the immediate vicinity - they are farther inland - but it does have a variety of agricultural activities that offer interesting tour options. Vancouver itself and the Greater Vancouver area offer a whole host of shopping, cultural, and educational options. The Vancouver Art Gallery features fine arts of past and present centuries. The Pacific Centre offers a central downtown experience that touches every aspect of life, from fashion to food, with boutique-style stores that stretch over three city blocks. Stanley Park covers 1,000 acres of woodlands offering nature trails, gardens, picnic sites, and special attractions at the zoological gardens. It is bordered by a 5.5-mile seawall, which provides cycle and pedestrian paths. The Vancouver Aquarium, located in Stanley Park, is the home of beluga whales, seals, sea otters, seabirds, and touch-pools. Vancouver's Chinatown, one of the largest Chinatowns in North America, features a commercial and market section as well as many different Chinese restaurants. The Museum of Anthropology offers an exciting and comprehensive display of unique art and icons of the West Coast Indian peoples. It features a large collection of Haida and Kwakiutl Indian carvings and totem poles along with an Asian and Pacific artifacts collection. Victoria, located on nearby Vancouver Island, offers the opportunity for a daylong tour, including a relaxing ferry ride. We are checking on fishing opportunities too!

\section{Dining}

The two headquarters hotels offer excellent, award-winning dining options. Beyond the hotels, within walking distance, a whole host of dining opportunities are available. A dining guide for Vancouver provides the following list of cuisine options (in alphabetical order): bar and grill, café/bistro, Canadian, Chinese, European, East Indian, family, fast food, First Nations, French, international, Italian, Japanese, Mediterranean, Mexican/Latin, nightlife/casino, pubs, seafood, South-east Asian, Spanish, steak and seafood, vegetarian, and West Coast.

\section{Shopping}

The immediate area around the hotels and Greater Vancouver offer a variety of shopping opportunities. Robson Street, a block from the hotels, is Vancouver's answer to Rodeo Drive. 
Granville Island, within 10 minutes of the hotels, is a shopper's paradise. It has the pleasant appeal of a bustling covered market and the presence of some of British Columbia's finest arts, crafts, and dining. Chinatown has a variety of specialty shops. Yaletown was once dominated by working warehouses, but is now a trendy place for galleries, spas, high fashion, and dining. Burnaby's Metrotown is BC's largest shopping and entertainment complex. It is accessible by SkyTrain.

\section{Public transportation}

The Vancouver transit system, TransLink, is made up of a network of buses and unique services such as the SeaBus and SkyTrain covering over 700 square miles of the greater mainland of Vancouver. TransLink makes getting around the city convenient, easy, and often provides beautiful views of the city!

\section{Currency}

Tourism Vancouver recommends all visitors use Canadian currency when traveling within Canada. Visitors can exchange currency at Canadian chartered banks, trust companies, or credit unions, or at offices of foreign exchange brokers, but it is advised to have local currency on hand prior to arriving. Some hotels, merchants, and restaurants accept US or other foreign currency at a predetermined rate, which may differ from the daily rate posted by financial institutions. Most major credit cards are accepted and recommended for purchases, but visitors who wish to pay by cash (US) are advised to check with the vendor before a purchase is made for the exchange rate that is being offered. Cash machines with 24-hour access are available in many convenient locations throughout Greater Vancouver.

- Canadian one dollar coin ("loonie") (\$1) =100 cents

- Canadian two dollar coin ("toonie") (\$2)=200 cents

- Notes are in denominations of $\$ 1,000, \$ 100, \$ 50, \$ 20, \$ 10, \$ 5$

- Coins are in denominations of $\$ 2, \$ 1, \$ 0.50, \$ 0.25, \$ 0.10$, $\$ 0.05, \$ 0.01$

On February 17, 2005, the exchange rate was $\$ 1.24$ CND to $\$ 1.00$ US. The exchange is favorable and shopping and dining in Vancouver can be an economically pleasant experience.

\section{Entry Regulations \\ US Citizens}

US citizens and permanent residents require a birth certificate, a resident alien card, or a green card together with a picture ID or passport to enter Canada. A driver's license is not accepted as proof of citizenship.

As of this writing (February 2005), we are exploring the need for a federal passport for those traveling on official fed- eral business, ie, when agencies are covering the cost of trav$\mathrm{el}$, hotel, and per diem.

Watch Membership News and the preconvention Trail Boss for information regarding student entry regulations.

\section{International Visitors}

Persons visiting from countries other than the United States must have a valid passport and may require other documentation such as visas. Check with the nearest Canadian consulate well in advance of travel.

\section{Border-to-Show Service}

In Vancouver, border-to-show customs service is available through our customs broker, Events on the Move. The broker will arrange for convention or meeting material to be forwarded directly to the convention site for clearance. Vancouver is one of only three cities in Canada that offers this invaluable service. Watch Membership News and the preconvention Trail Boss for information regarding shipping materials to Vancouver for the trade show and other meeting-related activities. The process can be smooth and easy as long as proper procedures are followed. Events on the Move will provide that service for us.

\section{Final Thoughts}

SRM's 2006 annual meeting in Vancouver will offer the usual excellent program of technical sessions, posters, workshops, and symposia. The SRM annual meeting is an exceptional opportunity to obtain continuing education for rangeland professionals. It provides an opportunity to network with fellow professionals. In addition to the professional reasons to attend the SRM annual meeting, this year Vancouver offers the additional opportunity to explore and enjoy a cosmopolitan Pacific Rim city that has been ranked among the most desirable cities in the world to visit. Bring your families a few days early or stay a few days later and enjoy this rare opportunity. More information about Vancouver can be obtained via the following Web site: www.tourismvancouver.com.

The Pacific Northwest Section SRM is excited about the 2006 meeting. We look forward to hosting you and your families in a truly beautiful and exciting city of the Pacific Northwest!

Authors are Local Arrangements cochairs for the SRM 2006 annual meeting and Department of Rangeland Resources, 202 Strand Hall, Oregon State University, Corvallis, OR 97331 (Borman) and 3771 Commonage Place, Vernon, BC, V1T 8M5 Canada (Meays). 